\title{
Pancreatic $\beta$-Cell Mass as a Pharmacologic Target in Diabetes
}

\author{
Stephen Hanley*
}

\begin{abstract}
While the prevalence of maternal While the prevalence of diabetes mellitus reaches epidemic proportions, most available treatments still focus on the symptoms of the disease, rather than the underlying pathology. Types 1 and 2 diabetes have in common a deficit in $\beta$-cell mass. In type 1 diabetes, auto-immune $\beta$-cell destruction leads to an absolute deficit in $\beta$-cells, while in type 2 diabetes, insulin resistance and $\beta$-cell dysfunction cause a functional deficit. More recently, however, it has been suggested that type 2 diabetes is also marked by an absolute deficit in $\beta$-cell mass, although a causal relationship has not yet been established. Overall $\beta$-cell mass reflects the balance between the dynamic processes of $\beta$-cell expansion, through proliferation and neogenesis, and $\beta$-cell loss via apoptosis. Given that $\beta$-cell mass can be modified significantly by altering the rate of any of these mechanisms, therapies that modulate $\beta$-cell expansion and loss have garnered recent interest. We review herein the current therapeutics under investigation as modulators of $\beta$-cell mass dynamics, and the basic research that supports these novel therapeutic targets.
\end{abstract}

KEYWORDS: $\beta$-cell mass, diabetes, islet neogenesis, pancreas, plasticity, regeneration

\section{INTRODUCTION}

Diabetes mellitus afflicts approximately $8 \%$ of Canadians, with an increasing incidence and prevalence $(1,2)$. Most will go on to develop complications, including cardiovascular disease, nephropathy, neuropathy and retinopathy, contributing to over $\$ 10$ billion per year in health-related costs (2).

While the etiologies differ between type 1 (T1DM) and type 2 diabetes (T2DM), both forms are characterized by a relative deficit in functional $\beta$-cell mass such that the insulin requirements of the body are not met and glycemia is uncontrolled. Thus, current therapies treat the symptoms of diabetes by normalizing glycemia, either by improving the insulin secretory output of the remaining $\beta$-cells (insulin secretagogues), improving the response to insulin at target tissues (insulin sensitizers), or replacing the missing insulin (exogenous insulin). As it stands, only isolated islet and

*To whom correspondence should be addressed: Stephen Hanley

Montreal General Hospital, C9-133

1650 Cedar avenue

Montréal, Québec, H3G 1A4, Canada

Email: stephen.hanley@mail.mcgill.ca solid organ pancreas transplantation address the deficit in $\beta$-cell mass that underlies diabetes, but these therapies are of limited clinical utility due to the shortage of donor organs and the side effects inherent to the immunosuppression that allo-grafts require. However, recent research suggests that the human pancreas may possess a significant regenerative capacity. Hence, new therapeutic strategies seek to harness this regeneration to re-establish a functional $\beta$ cell mass that is sufficient to normalize glycemia and reverse diabetes.

\section{Type 1 Diabetes Mellitus}

While the exact nature of the insult remains to be elucidated, T1DM is characterized by the destruction of pancreatic $\beta$-cells due to T-cell-mediated auto-immune attack (3). Clinical onset is associated with a residual $\beta$ cell mass comprising approximately $20 \%$ that of agematched non-diabetic individuals (4). It is at this point that the remaining $\beta$-cell mass is incapable of maintaining normoglycemia, and persistent hyperglycemia occurs.

Thus, the current treatment for T1DM consists of insulin replacement, either by the administration of 
exogenous insulin in a manner that seeks to mimic the secretory response of $\beta$-cells, or by the replacement of the missing $\beta$-cell mass by the transplantation of solidorgan pancreas or isolated islets allo-grafts. Unfortunately, while exogenous insulin administration may delay or slow the development of diabetic complications, this treatment cannot prevent their occurrence $(5,6)$. Conversely, solid organ pancreas transplant represents the only available means of providing long-term glycemic control that prevents, and even, reverses diabetic complications (7), by way of reestablishing an appropriately functional $\beta$-cell mass. However, life-long immunosuppression, with all the associated side effects, along with the limited availability of cadaveric donor organs, limits any transplantation-based approach. With respect to islet transplantation, it was hypothesized that the islets isolated from one donor organ could be used to treat several recipients, given that overt diabetes is only observed when there is a $\geq 50 \%$ reduction in $\beta$-cell mass (4). However, the attrition associated with the isolation process results in several donor organs being required per individual recipient, while the average duration of graft function reaching only 15 months in islet recipients (8), as compared to ten years in pancreas recipients (7). Thus, none of the currently available treatments is ideal.

While it stands to reason that the auto-immune attack responsible for T1DM would eventually result in a complete loss of $\beta$-cell mass, recent case reports of elderly individuals with long-standing T1DM indicate ongoing $\beta$-cell apoptosis $(9,10)$, suggesting that attempts at $\beta$-cell regeneration within the native pancreas may persist throughout the duration of the disease. The rate of such regenerative mechanisms is obviously eclipsed by the rate of $\beta$-cell death in individuals with T1DM, but this observation does suggest nonetheless that the manipulation of rates of $\beta$ cell formation and death could be a possible therapeutic target in diabetes.

\section{Type 2 Diabetes Mellitus}

T2DM accounts for the vast majority of cases of diabetes, and is a heterogeneous disease marked by $\beta$ cell dysfunction $(11,12)$ combined with insulin resistance in target tissues $(11,13,14)$. The pathogenesis of the disease involves both genetic (15) and environmental factors, and is frequently associated with obesity $(13,16-18)$.

With respect to $\beta$-cell dysfunction, clinical studies have highlighted the impaired first-phase insulin secretion that is common in T2DM (19-21). Moreover, in vitro studies of isolated human islets indicate that insulin content and the insulin secretory response to a glucose challenge are decreased in T2DM (22-25). Thus, a normal $\beta$-cell mass may not necessarily correlate with normal glucose tolerance (26), suggesting that the $\beta$-cell deficit in T2DM may be functional, as opposed to absolute $(4,27-34)$.

It is for these reasons that the current pharmaceutical options for the management of T2DM fall into two broad categories; those of insulin secretagogues compounds that increase the insulin secretory response of the $\beta$-cell - and insulin sensitizers - compounds that potentiate the effect of insulin at its target tissues. While these medications are certainly useful in the management of the disease, the fact remains that a significant proportion of patients with T2DM eventually require exogenous insulin due to the progressive loss of $\beta$-cell function and increase in insulin resistance.

However, recent data now suggests that T2DM is also characterized by an absolute deficit in $\beta$-cell mass (35, 36). In fact, a step-wise decline in $\beta$-cell mass is observed over the progression from normoglycemia to impaired fasting glucose to overt diabetes (35). With respect to the mechanism of this loss of $\beta$-cell mass, it would appear that the rate of $\beta$-cell apoptosis is increased in T2DM, while the rate of $\beta$-cell formation is unchanged (35). Moreover, it seems that the hyperglycemic hyperlipidemic environment that is found in T2DM is directly toxic to pancreatic $\beta$-cells $(37,38)$, further propagating this cycle (39-41). Thus, interventions designed to either slow the rate of $\beta$-cell apoptosis, or stimulate the formation of new $\beta$-cells may be of clinical utility in the management of T2DM.

\section{$\beta$-Cell Mass}

Pancreatic $\beta$-cell mass is not a static entity, but rather is in constant flux, and as such can adapt to the prevailing physiologic needs $(42,43)$. For example, insulin resistance associated with pregnancy (44) or obesity $(4,35,45)$ leads to as much as a doubling of $\beta$ cell mass. Conversely, a deficit in $\beta$-cell mass is associated with diabetes $(9,35)$.

Changes in $\beta$-cell mass over time reflect the net effect of diametrically opposed pathways; those that serve to increase $\beta$-cell mass, and those that serve to decrease it. Possible $\beta$-cell mass expansion pathways include $\beta$-cell hypertrophy and replication, as well as the formation of new $\beta$-cells from non- $\beta$-cell sources - neogenesis. Each of these factors has an equivalent opposing force; $\beta$-cell atrophy and death, via apoptosis or necrosis, as well as $\beta$-cell dedifferentiation, all serve to decrease $\beta$-cell mass. However, studies suggest that the three main mechanisms at play in controlling $\beta$-cell mass dynamics are $\beta$-cell replication, neogenesis and death $(35,46,47)$.

Based on these observations, Finegood et al. (42) 
proposed a simple mass-balance equation to follow the prevailing trends in $\beta$-cell mass:

$$
\begin{gathered}
\mathrm{d}(\beta \text {-cell mass }) / \mathrm{dt}=\text { rate } \beta \text {-cell replication }+ \text { rate } \beta \text {-cell } \\
\text { neogenesis }- \text { rate } \beta \text {-cell death. }
\end{gathered}
$$

While $\beta$-cell mass is highly dynamic, and represents the sum of several processes, the methods for estimating overall $\beta$-cell mass and the rates of change are static. Moreover, no current technology exists to accurately assess these parameters in situ. Thus, studies of $\beta$-cell mass in humans are limited to autopsy cases and cadaveric donor organs, with rates of changes presented as relative, rather than absolute values (35, 36). Nevertheless, these studies provide indications of these mechanisms in non-diabetic humans, and suggest the effects of diabetes on the mechanisms that control $\beta$ cell mass.

As indicated earlier, human diabetes is marked by a deficit in functional $\beta$-cell mass. While patients suffering from T1DM have a virtual lack of $\beta$-cell mass (4), chronic $\beta$-cell apoptosis in individuals with T1DM suggests $\beta$-cell neogenesis is also ongoing $(9,10)$. Recent evidence also indicates that increased $\beta$-cell apoptosis also leads to a deficit in $\beta$-cell mass in T2DM (35). This increased $\beta$-cell apoptosis is observed in both lean and obese cases of T2DM, while obese T2DM individuals do show evidence of increased neogenesis and lean T2DM individuals have increased $\beta$-cell proliferation indices, suggesting compensatory mechanisms are intact, but outpaced by $\beta$-cell apoptosis (35). Thus, these findings suggest that regenerative mechanisms do exist within the human pancreas, and it may be possible to manipulate the rates of the various components to affect overall $\beta$-cell mass.

\section{Limiting $\beta$-Cell Loss}

The mechanisms responsible for depleting $\beta$-cell mass are well defined, and are predominated by $\beta$-cell death $(35,42)$, either in the form of apoptosis or necrosis. Increased $\beta$-cell death is common to both T1DM (3) and T2DM (35), however efforts at controlling this aspect of $\beta$-cell mass have been limited. While the auto-immune nature of T1DM suggests that attenuation of the immune response may help to preserve $\beta$-cell mass, results of clinical trials have not supported this therapeutic avenue (48). Likewise, while inhibition of $\beta$-cell apoptosis would likely be a useful therapy in T2DM, few agents have any specificity for pancreatic $\beta$-cells (49-52), and systemic administration of a generic anti-apoptotic agent is simply unfeasible.

\section{Inducing $\beta$-Cell Expansion}

The mechanisms of increasing $\beta$-cell mass are still highly controversial $(53,54)$. The two principal mechanisms of increasing $\beta$-cell mass are replication the formation of $\beta$-cells by the division of pre-existing $\beta$-cells - and neogenesis - the formation of $\beta$-cells from non- $\beta$-cell precursors (55-59).

\section{$\beta$-Cell Replication}

While the adult $\beta$-cell turnover rate is low (60), in vivo and in vitro studies have determined that $\beta$-cells proliferate in response to physiologic concentrations of relevant growth factors (61-68). Recent evidence suggests that $\beta$-cell proliferation may function as a compensatory mechanism in $\mathrm{T} 2 \mathrm{DM}(35,46)$, although proliferating $\beta$-cells are also more susceptible to apoptosis $(69,70)$. Thus, $\beta$-cell replication is a real, semi-quantifiable component of $\beta$-cell mass dynamics, both in the normal and diseased pancreas. However, unbridled cell proliferation is a hallmark of cancer, and as such care must be taken to ensure a physiologic, selflimiting level of proliferation.

\section{$\beta$-Cell Neogenesis}

Although $\beta$-cell replication and neogenesis are dynamic processes, the availability of detectable markers of cellular proliferation $(71,72)$ renders the quantification of cell replication much more straightforward than the measurement of neogenesis. Recent advances in lineage tracing techniques have facilitated the process, but questions regarding the cell(s) of origin and inter-species differences mean that neogenesis is still a polarizing subject.

Neogenesis implies that $\beta$-cells form from non- $\beta$-cell precursors (56-58), though the source and location of such precursors is not specified. Thus, the term neogenesis could be applied to the formation of $\beta$-cells from intra- or extra-pancreatic stem cells, as well as the direct or indirect transdifferentiation of other adult cell types. Regardless of the exact nature of the cell(s) of origin, neogenesis represents a means of expanding pancreatic $\beta$-cell mass.

\section{Regenerative Factors}

A variety of animal models have been developed to study the mechanisms of islet regeneration, and identify the factors involved. These models include partial pancreatic duct obstruction $(57,73)$ or ligation $(74,75)$, partial pancreatectomy $(58,76)$, chronic and acute glucose infusion (77-79), administration of a $\beta$-cellspecific toxin (80) and transgenic models (81-83), all of which are associated with an endogenous pancreatic regenerative response. As such, researchers have screened the regenerating pancreas to identify factors that may regulate the response, as well as general changes in gene expression $(84,85)$. 
Several novel therapeutics have been developed based on these studies, all of which are currently in clinical trials as novel therapies for diabetes.

\section{Gastrin and Epidermal Growth Factor}

Studies of the pancreatic regenerative response to pancreatic duct ligation (74) noted the upregulation of gastrin and transforming growth factor- $\beta$, a member of the epidermal growth factor (EGF) family of ligands (75). Subsequent studies indicated that alone, these factors acted mainly as duct cell mitogens (86-88), whereas co-administration or generation of double transgenic animals led to a significant increase in $\beta$-cell mass $(82,89,90)$. It now appears that the role of EGF ligands may be to generate metaplastic duct-like structures derived from acinar tissue (91, 92), which then go on to form islets in response to gastrin (93).

In vitro studies suggest that human tissue can be expanded and differentiated in the same way (94-96). There is also pathologic evidence for such an islet regenerative effect of gastrin, as Zollinger-Ellison syndrome - hypergastrinemia secondary to a gastrinoma - is associated with increased islet neogenesis and replication $(97,98)$.

Based on the above studies, combination therapy with gastrin and EGF analogues is currently in clinical trials (99), although due to the established carcinogenicity of EGF, more recent trials focus on gastrin and glucagonlike peptide-1 (GLP-1) co-administration (100). Nonetheless, preliminary data from phase IIa clinical trials indicate that EGF and GLP-1 analogue coadministration improve glycemic control, as reflected by $\mathrm{HbA1c}$, fasting glucose and glucose tolerance (101). While clinically important and suggestive of mechanism, these outcomes do not necessarily indicate an increase in endogenous $\beta$-cell mass.

\section{Glucagon-like Peptide-1}

GLP-1 is a product of alternative post-translational modification of preproglucagon (102). While $\beta$-cells produce and secrete glucagon, enteroendocrine L-cells of the intestine produce GLP-1 (103). Due to their incretin and other effects (104), long-acting GLP-1 analogues (105) and dipeptidyl peptidase-IV inhibitors (106) are already available for the treatment of T2DM. Additionally, however, GLP-1 has been implicated in islet regeneration $(64,107-113)$, leading to its study as a regenerative factor.

Data regarding the regenerative role of GLP-1 and related agonists are controversial. There is strong evidence to suggest that GLP-1 receptor activation can protect $\beta$-cells from apoptosis (49-52). There is equally convincing evidence of a $\beta$-cell mitogenic effect of GLP-1 (49, 64, 108, 114). However, while there are reports of GLP-1-mediated islet neogenesis $(64,109$, $112,113,115)$, recent statements by researchers examining the in vivo effects of GLP-1 call into question a neogenic response (116-120). Nevertheless, GLP-1 certainly has a role to play in the evolving treatment of diabetes, if not as a neogenic factor then at least with its capacity to act as a $\beta$-cell mitogen and anti-apoptotic supplementing its activity as an incretin.

\section{Reg Proteins}

Given that subtotal pancreatectomy combined with poly(ADP-ribose) polymerase inhibitor treatment promotes islet regeneration (121), researchers screening a cDNA library generated from the regenerating islets identified a novel protein, termed regenerating protein (Reg, now known as RegI) (122). It was later determined that while some Reg proteins are expressed in regenerating islets (123), expression is primarily at acinar tissue (124).

Reg proteins have been postulated to play a role in inhibition of pancreatic stone formation (125), bacterial aggregation (126), regulation of inflammation (127, 128 ) and cellular adhesion to extracellular matrix components (129), among others. Most interestingly, however, in vivo studies suggest that administration of RegI may be sufficient to induce pancreatic regeneration in both surgically-induced (62) and genetic (130-133) models of diabetes. Moreover, RegIoverexpressing mice have increased islet proliferation, and crossing unto a genetic background of diabetes (NOD) delays the onset of diabetes and increases $\beta$-cell mass (134). RegI-/- animals are not overtly diseased, although islet proliferation is reduced (134). Reg proteins are mitogenic to islet and ductal cell lines, as well as isolated islets and primary duct cultures (135$137)$, and may also have anti-apoptotic effects (128, 138).

While the exact Reg mechanism of action and signalling pathways are still contentious (139), it is noteworthy that Reg expression or activity has been associated with other putative regenerative factors. For example, administration of a GLP-1 analogue upregulates pancreatic Reg expression prior to observation of islet regeneration (85), while the effects of gastrin may be mediated by Reg expression (140, 141).

Thus, while results are promising, Reg proteins, with the exception of one, have not elicited much clinical interest.

\section{Islet Neogenesis-Associated Protein}

The Reg proteins can be divided into three general families; RegI, RegIII and Reg IV (142). The RegIII subfamily is characterized by the presence of a five 
amino acid insert, which would likely be found on an outside turn in the three-dimensional structure of the protein, based on available models (143). Islet neogenesis-associated protein (INGAP) is the only RegIII protein identified in hamsters, although two family members exist in humans, and four exist in mice, including one - RegIII $\delta$ - that is highly homologous to INGAP (144).

INGAP was discovered in a surgical model of partial pancreatic duct obstruction associated with increased $\beta$ cell mass and what appeared to be foci of islet neogenesis (57). Initial work identified a crude pancreatic extract containing biological activity (145), while subsequent genetic work identified INGAP as the main biologically active compound (135). Based on three-dimensional modelling and sequence comparisons, a synthetic 15 amino acid fragment was designed, which includes the aforementioned five amino acid insert. This fragment (INGAP104-118), termed INGAP peptide, was shown to induce the proliferation of primary ductal cultures and ductal cell lines (135).

While identified initially in partially pancreatic ductobstructed hamsters, INGAP was subsequently found to be upregulated in other models of islet regeneration, including sucrose administration in hamster drinking water (146), sucrose administration to pregnant hamsters (147), chronically glucose-infused rats and diabetes-prone BioBreeding rats (96).

Administration of INGAP peptide increases $\beta$-cell mass sufficiently to reverse chemically-induced diabetes in mice (148). While INGAP peptide did not reverse diabetes in chronically diabetic NOD mice, coadministration with immunosuppression improved survival and indices of diabetes severity (96). Studies on isolated rat islets indicate that acute INGAP peptide treatment can increase both basal and stimulated insulin secretion from isolated rat islets (149).

Interestingly, while administration of INGAP peptide to normoglycemic hamsters (148), mice (47) or monkeys (96) does induce islet neogenesis and $\beta$-cell mass expansion, this increase appears to be transient, at least in healthy animals. Based on this observation, it has been proposed that the mechanisms of $\beta$-cell mass dynamics are actively regulating $\beta$-cell mass, even in the context of induced islet neogenesis (47).

While no direct human homologue appears to exist for INGAP, studies using in vitro cultures of human islet- or acinar-derived tissue indicate that the islet regenerative potential of INGAP peptide also extends to human tissue $(95,150)$. Clinical trials have also yielded promising results, showing an increase in argininestimulated C-peptide levels in T1DM patients (151), and a decrease in HbAlc in T2DM patients (152).

\section{CONCLUSION}

While the therapies currently available for the management of diabetes are relatively successful at controlling the symptoms of this disease, the fact remains that the underlying cause of these symptoms goes unaddressed. Thus, the majority of patients with diabetes will develop secondary complications of the disease resulting in shortened lifespan and reduced quality of life. Recent insights into the etiology of diabetes have offered a suggestion as to new therapeutic opportunities for the treatment of diabetes, namely the re-establishment of a functional $\beta$-cell mass that is sufficient for glycemic control. Thus, new therapies are being designed and tested that seek to re-establish a significant population of functional $\beta$-cells in the endogenous pancreas, either by inhibiting the destruction of pre-existing $\beta$-cells, or inducing the formation of new $\beta$-cells. However, any therapy that seeks to manipulate the balance between cell death and survival, and differentiation and proliferation, also carries with it the risk of carcinogenicity. This risk is of particular concern given that the clinical interest in these novel therapies is not necessarily reflective of our level of understanding of the mechanisms of control of $\beta$-cell mass dynamics. However, given the inherent ability of the body to manipulate $\beta$-cell mass in response to specific metabolic conditions $(4,35,42-$ 45 ), and a recent report that suggests that the body's ability to regulate $\beta$-cell mass remains intact even in the context of external manipulation (47), it would appear that therapies designed at re-establishing a functional endogenous $\beta$-cell mass possess a significant potential as novel therapies for diabetes.

\section{ACKNOWLEDGEMENTS}

This work was supported by fellowships from the Canadian Diabetes Association / Canadian Institutes of Health Research and Fonds de Recherche en Santé du Québec.

\section{REFERENCES}

1. Meltzer S, Leiter L, Daneman D, Gerstein HC, Lau D, Ludwig $\mathrm{S}$, et al. 1998 clinical practice guidelines for the management of diabetes in Canada. Can Med Assoc J. 1998;159(Suppl 8):S1-29.

2. Tan MH, MacLean DR. Epidemiology of diabetes mellitus in Canada. Clin Invest Med. 1995 Aug;18(4):240-6.

3. Atkinson MA, Eisenbarth GS. Type 1 diabetes: new perspectives on disease pathogenesis and treatment. Lancet. 2001 Jul 21;358(9277):221-9.

4. Kloppel G, Lohr M, Habich K, Oberholzer M, Heitz PU. Islet pathology and the pathogenesis of type 1 and type 2 diabetes mellitus revisited. Surv Synth Pathol Res. 1985;4(2):110-25.

5. The effect of intensive treatment of diabetes on the development and progression of long-term complications in insulin-dependent diabetes mellitus. N Engl J Med. 1993 Sep 30;329(14):977-86. 
6. Sustained effect of intensive treatment of type 1 diabetes mellitus on development and progression of diabetic nephropathy: the Epidemiology of Diabetes Interventions and Complications (EDIC) study. JAMA. 2003 Oct 22;290(16):2159-67.

7. Sutherland DE, Gruessner RW, Gruessner AC. Pancreas transplantation for treatment of diabetes mellitus. World J Surg. 2001 Apr;25(4):487-96.

8. Ryan EA, Paty BW, Senior PA, Bigam D, Alfadhli E, Kneteman NM, et al. Five-year follow-up after clinical islet transplantation. Diabetes. 2005 Jul;54(7):2060-9.

9. Meier JJ, Bhushan A, Butler AE, Rizza RA, Butler PC. Sustained beta cell apoptosis in patients with long-standing type 1 diabetes: indirect evidence for islet regeneration? Diabetologia. 2005 Nov;48(11):2221-8.

10. Meier JJ, Lin JC, Butler AE, Galasso R, Martinez DS, Butler PC. Direct evidence of attempted beta cell regeneration in an 89-year-old patient with recent-onset type 1 diabetes. Diabetologia. 2006 Aug;49(8):1838-44.

11. Kahn SE. The relative contributions of insulin resistance and beta-cell dysfunction to the pathophysiology of type 2 diabetes. Diabetologia. 2003 Jan;46(1):3-19.

12. Rhodes CJ. Type 2 diabetes - a matter of beta-cell life and death? Science. 2005 Jan 21;307(5708):380-4.

13. Yki-Jarvinen H. Role of insulin resistance in the pathogenesis of NIDDM. Diabetologia. 1995 Dec;38(12):1378-88.

14. Saltiel AR. New perspectives into the molecular pathogenesis and treatment of type 2 diabetes. Cell. 2001 Feb 23;104(4):517-29.

15. Sladek R, Rocheleau G, Rung J, Dina C, Shen L, Serre D, et al. A genome-wide association study identifies novel risk loci for type 2 diabetes. Nature. 2007 Feb 22;445(7130):881-5.

16. Karam JH. Type II diabetes and syndrome X. Pathogenesis and glycemic management. Endocrinol Metab Clin North Am. 1992 Jun;21(2):329-50.

17. Zimmet PZ. Diabetes epidemiology as a tool to trigger diabetes research and care. Diabetologia. 1999 May;42(5):499-518.

18. Baggio LL, Drucker DJ. Therapeutic approaches to preserve islet mass in type 2 diabetes. Annu Rev Med. 2006;57:265-81.

19. Gumbiner B, Van Cauter E, Beltz WF, Ditzler TM, Griver K, Polonsky KS, et al. Abnormalities of insulin pulsatility and glucose oscillations during meals in obese noninsulindependent diabetic patients: effects of weight reduction. J Clin Endocrinol Metab. 1996 Jun;81(6):2061-8.

20. Gerich JE. The genetic basis of type 2 diabetes mellitus: impaired insulin secretion versus impaired insulin sensitivity. Endocr Rev. 1998 Aug;19(4):491-503.

21. Del Prato S, Marchetti P, Bonadonna RC. Phasic insulin release and metabolic regulation in type 2 diabetes. Diabetes. 2002 Feb;51 Suppl 1:S109-16.

22. Marchetti P, Del Guerra S, Marselli L, Lupi R, Masini M, Pollera M, et al. Pancreatic islets from type 2 diabetic patients have functional defects and increased apoptosis that are ameliorated by metformin. J Clin Endocrinol Metab. 2004 Nov;89(11):5535-41.

23. Deng S, Vatamaniuk M, Huang X, Doliba N, Lian MM, Frank A, et al. Structural and functional abnormalities in the islets isolated from type 2 diabetic subjects. Diabetes. 2004 Mar;53(3):624-32.

24. Anello M, Lupi R, Spampinato D, Piro S, Masini M, Boggi U, et al. Functional and morphological alterations of mitochondria in pancreatic beta cells from type 2 diabetic patients. Diabetologia. 2005 Feb;48(2):282-9.

25. Ostenson CG, Gaisano H, Sheu L, Tibell A, Bartfai T. Impaired gene and protein expression of exocytotic soluble $\mathrm{N}$ ethylmaleimide attachment protein receptor complex proteins in pancreatic islets of type 2 diabetic patients. Diabetes. 2006 Feb;55(2):435-40.

26. Ritzel RA, Butler AE, Rizza RA, Veldhuis JD, Butler PC. Relationship between beta-cell mass and fasting blood glucose concentration in humans. Diabetes Care. 2006 Mar;29(3):7178.

27. Maclean N, Ogilvie RF. Quantitative estimation of the pancreatic islet tissue in diabetic subjects. Diabetes. 1955 SepOct;4(5):367-76.

28. Gepts W. Contribution à l'étude morphologique des îlots de Langerhans au cours du diabète. Ann Soc R Sci Med Nat Brux. 1957;10(1):5-108.

29. Saito K, Yaginuma N, Takahashi T. Differential volumetry of $\mathrm{A}, \mathrm{B}$ and $\mathrm{D}$ cells in the pancreatic islets of diabetic and nondiabetic subjects. Tohoku J Exp Med. 1979 Nov;129(3):273-83.

30. Stefan Y, Orci L, Malaisse-Lagae F, Perrelet A, Patel Y, Unger $\mathrm{RH}$. Quantitation of endocrine cell content in the pancreas of nondiabetic and diabetic humans. Diabetes. 1982 Aug;31(8 Pt 1):694-700.

31. Rahier J, Goebbels RM, Henquin JC. Cellular composition of the human diabetic pancreas. Diabetologia. 1983 May;24(5):366-71.

32. Clark A, Wells CA, Buley ID, Cruickshank JK, Vanhegan RI, Matthews DR, et al. Islet amyloid, increased A-cells, reduced B-cells and exocrine fibrosis: quantitative changes in the pancreas in type 2 diabetes. Diabetes Res. 1988 Dec;9(4):1519.

33. Guiot Y, Sempoux C, Moulin P, Rahier J. No decrease of the beta-cell mass in type 2 diabetic patients. Diabetes. 2001;50(Suppl 1):S188.

34. Sakuraba H, Mizukami H, Yagihashi N, Wada R, Hanyu C, Yagihashi S. Reduced beta-cell mass and expression of oxidative stress-related DNA damage in the islet of Japanese Type II diabetic patients. Diabetologia. 2002 Jan;45(1):85-96.

35. Butler AE, Janson J, Bonner-Weir S, Ritzel R, Rizza RA, Butler PC. Beta-cell deficit and increased beta-cell apoptosis in humans with type 2 diabetes. Diabetes. 2003 Jan;52(1):102-10.

36. Rahier J, Guiot Y, Goebbels RM, Sempoux C, Henquin JC. Pancreatic beta-cell mass in European subjects with type 2 diabetes. Diabetes Obes Metab. 2008 Nov;10 Suppl 4:32-42.

37. Maedler K, Spinas GA, Lehmann R, Sergeev P, Weber M, Fontana A, et al. Glucose induces beta-cell apoptosis via upregulation of the Fas receptor in human islets. Diabetes. 2001 Aug;50(8):1683-90.

38. El-Assaad W, Buteau J, Peyot ML, Nolan C, Roduit R, Hardy $\mathrm{S}$, et al. Saturated fatty acids synergize with elevated glucose to cause pancreatic beta-cell death. Endocrinology. 2003 Sep;144(9):4154-63.

39. Prentki M, Joly E, El-Assaad W, Roduit R. Malonyl-CoA signaling, lipid partitioning, and glucolipotoxicity: role in betacell adaptation and failure in the etiology of diabetes. Diabetes. 2002 Dec;51 Suppl 3:S405-13.

40. Poitout V, Robertson RP. Minireview: Secondary beta-cell failure in type 2 diabetes--a convergence of glucotoxicity and lipotoxicity. Endocrinology. 2002 Feb;143(2):339-42.

41. Cnop M, Welsh N, Jonas JC, Jorns A, Lenzen S, Eizirik DL. Mechanisms of pancreatic beta-cell death in type 1 and type 2 diabetes: many differences, few similarities. Diabetes. 2005 Dec;54 Suppl 2:S97-107.

42. Finegood DT, Scaglia L, Bonner-Weir S. Dynamics of beta-cell mass in the growing rat pancreas. Estimation with a simple mathematical model. Diabetes. 1995 Mar;44(3):249-56.

43. Bonner-Weir S. Beta-cell turnover: its assessment and implications. Diabetes. 2001 Feb;50 Suppl 1:S20-4.

44. Scaglia L, Smith FE, Bonner-Weir S. Apoptosis contributes to 
the involution of beta cell mass in the post partum rat pancreas. Endocrinology. 1995 Dec;136(12):5461-8.

45. Ogilvie RF. The islands of langerhans in 19 cases of obesity. J Pathol Bacteriol. 1933;37(3):473-81.

46. Butler AE, Janson J, Soeller WC, Butler PC. Increased betacell apoptosis prevents adaptive increase in beta-cell mass in mouse model of type 2 diabetes: evidence for role of islet amyloid formation rather than direct action of amyloid. Diabetes. 2003 Sep;52(9):2304-14.

47. Lipsett MA, Austin EB, Castellarin ML, Lemay J, Rosenberg L. Evidence for the homeostatic regulation of induced beta cell mass expansion. Diabetologia. 2006 Dec;49(12):2910-9.

48. Raz I, Elias D, Avron A, Tamir M, Metzger M, Cohen IR. Betacell function in new-onset type 1 diabetes and immunomodulation with a heat-shock protein peptide (DiaPep277): a randomised, double-blind, phase II trial. Lancet. 2001 Nov 24;358(9295):1749-53.

49. Farilla L, Hui H, Bertolotto C, Kang E, Bulotta A, Di Mario U, et al. Glucagon-like peptide-1 promotes islet cell growth and inhibits apoptosis in Zucker diabetic rats. Endocrinology. 2002 11/2002;143(11):4397-408.

50. Li Y, Hansotia T, Yusta B, Ris F, Halban PA, Drucker DJ. Glucagon-like peptide-1 receptor signaling modulates beta cell apoptosis. J Biol Chem. 2003 Jan 3;278(1):471-8.

51. Hui H, Nourparvar A, Zhao X, Perfetti R. Glucagon-like peptide-1 inhibits apoptosis of insulin-secreting cells via a cyclic 5'-adenosine monophosphate-dependent protein kinase A- and a phosphatidylinositol 3-kinase-dependent pathway. Endocrinology. 2003 4/2003;144(4):1444-55.

52. Farilla L, Bulotta A, Hirshberg B, Li Calzi S, Khoury N, Noushmehr H, et al. Glucagon-like peptide 1 inhibits cell apoptosis and improves glucose responsiveness of freshly isolated human islets. Endocrinology. 2003 Dec;144(12):514958.

53. Dor Y. Beta-cell proliferation is the major source of new pancreatic beta cells. Nat Clin Pract Endocrinol Metab. 2006 May;2(5):242-3.

54. Bonner-Weir S, Sharma A. Are there pancreatic progenitor cells from which new islets form after birth? Nat Clin Pract Endocrinol Metab. 2006 May;2(5):240-1.

55. Cecil RL. On hypertrophy and regeneration of the islands of Langerhans. J Exp Med. 1911;14:500-19.

56. Rosenberg L, Brown RA, Duguid WP. Induction of experimental nesidioblastosis - A model to study pancreaticislet cell-differentiation and function. Surgical Forum. 1982;33:227-30.

57. Rosenberg L, Brown RA, Duguid WP. A new approach to the induction of duct epithelial hyperplasia and nesidioblastosis by cellophane wrapping of the hamster pancreas. J Surg Res. 1983 Jul;35(1):63-72.

58. Bonner-Weir S, Baxter LA, Schuppin GT, Smith FE. A second pathway for regeneration of adult exocrine and endocrine pancreas. A possible recapitulation of embryonic development. Diabetes. 1993 Dec;42(12):1715-20.

59. Bouwens L, Pipeleers DG. Extra-insular beta cells associated with ductules are frequent in adult human pancreas. Diabetologia. 1998 Jun;41(6):629-33.

60. Hellerstrom C, Swenne I, Andersson A. Islet cell replication and diabetes. In: Lefebvre PJ, Pipeleers DG, editors. The Pathology of the Endocrine Pancreas in Diabetes. Heidelberg: Springer-Verlag; 1988. p. 141-70.

61. Scharfmann R, Basmaciogullari A, Czernichow P. Effect of growth hormone and glucose on rat islet cells replication using 5-bromo-2-deoxyuridine incorporation. Diabetes Res. 1990 Nov;15(3):137-41.

62. Watanabe T, Yonemura Y, Yonekura H, Suzuki Y, Miyashita H,
Sugiyama K, et al. Pancreatic beta-cell replication and amelioration of surgical diabetes by Reg protein. Proc Natl Acad Sci. 1994 Apr 26;91(9):3589-92.

63. Montana E, Bonner-Weir S, Weir GC. Beta cell replication and mass in islet transplantation. Adv Exp Med Biol. 1997;426:421-7.

64. Xu G, Stoffers DA, Habener JF, Bonner-Weir S. Exendin-4 stimulates both beta-cell replication and neogenesis, resulting in increased beta-cell mass and improved glucose tolerance in diabetic rats. Diabetes. 1999 Dec;48(12):2270-6.

65. Nielsen JH, Svensson C, Galsgaard ED, Moldrup A, Billestrup N. Beta cell proliferation and growth factors. J Mol Med. 1999 Jan;77(1):62-6.

66. Akiyama T, Takasawa S, Nata K, Kobayashi S, Abe M, Shervani NJ, et al. Activation of Reg gene, a gene for insulinproducing beta-cell regeneration: poly(ADP-ribose) polymerase binds Reg promoter and regulates the transcription by autopoly(ADP-ribosyl)ation. Proc Natl Acad Sci. 2001 Jan 2;98(1):48-53.

67. Vasavada RC, Gonzalez-Pertusa JA, Fujinaka Y, FiaschiTaesch N, Cozar-Castellano I, Garcia-Ocana A. Growth factors and beta cell replication. Int J Biochem Cell Biol. 2006;38(56):931-50.

68. Friedrichsen BN, Neubauer N, Lee YC, Gram VK, Blume N, Petersen JS, et al. Stimulation of pancreatic beta-cell replication by incretins involves transcriptional induction of cyclin D1 via multiple signalling pathways. J Endocrinol. 2006 Mar;188(3):481-92.

69. Ritzel RA, Butler PC. Replication increases beta-cell vulnerability to human islet amyloid polypeptide-induced apoptosis. Diabetes. 2003 Jul;52(7):1701-8.

70. Meier JJ, Ritzel RA, Maedler K, Gurlo T, Butler PC. Increased vulnerability of newly forming beta cells to cytokine-induced cell death. Diabetologia. 2006 Jan;49(1):83-9.

71. Montana E, Bonner-Weir S, Weir GC. Transplanted beta cell response to increased metabolic demand. Changes in beta cell replication and mass. J Clin Invest. 1994 Apr;93(4):1577-82.

72. Kaung HL. Growth dynamics of pancreatic islet cell populations during fetal and neonatal development of the rat. Dev Dyn. 1994 Jun;200(2):163-75.

73. Alawadhi A, Duguid WP, Rosenberg L, Brown R. Reversal of Diabetes by Surgical Induction of Nesidioblastosis. Clin Invest Med. 1986;9(3):A66-A.

74. Wang RN, Kloppel G, Bouwens L. Duct- to islet-cell differentiation and islet growth in the pancreas of duct-ligated adult rats. Diabetologia. 1995 Dec;38(12):1405-11.

75. Wang RN, Rehfeld JF, Nielsen FC, Kloppel G. Expression of gastrin and transforming growth factor-alpha during duct to islet cell differentiation in the pancreas of duct-ligated adult rats. Diabetologia. 1997 Aug;40(8):887-93.

76. Brockenbrough JS, Weir GC, Bonner-Weir S. Discordance of exocrine and endocrine growth after $90 \%$ pancreatectomy in rats. Diabetes. 1988 Feb;37(2):232-6.

77. Bonner-Weir S, Deery D, Leahy JL, Weir GC. Compensatory growth of pancreatic beta-cells in adult rats after short-term glucose infusion. Diabetes. 1989 Jan;38(1):49-53.

78. Lipsett M, Finegood DT. Beta-cell neogenesis during prolonged hyperglycemia in rats. Diabetes. 2002 Jun;51(6):1834-41.

79. Topp BG, McArthur MD, Finegood DT. Metabolic adaptations to chronic glucose infusion in rats. Diabetologia. 2004 Sep;47(9):1602-10.

80. Fernandes A, King LC, Guz Y, Stein R, Wright CV, Teitelman G. Differentiation of new insulin-producing cells is induced by injury in adult pancreatic islets. Endocrinology. 1997 Apr;138(4):1750-62. 
81. Gu D, Sarvetnick N. Epithelial cell proliferation and islet neogenesis in IFN-gamma transgenic mice. Development. 1993 May;118(1):33-46.

82. Wang TC, Bonner-Weir S, Oates PS, Chulak M, Simon B, Merlino GT, et al. Pancreatic gastrin stimulates islet differentiation of transforming growth factor alpha-induced ductular precursor cells. J Clin Invest. 1993 Sep;92(3):134956

83. Lu Y, Herrera PL, Guo Y, Sun D, Tang Z, LeRoith D, et al. Pancreatic-specific inactivation of IGF-I gene causes enlarged pancreatic islets and significant resistance to diabetes. Diabetes. 2004 Dec;53(12):3131-41.

84. Lu Y, Ponton A, Okamoto H, Takasawa S, Herrera PL, Liu JL. Activation of the Reg family genes by pancreatic-specific IGFI gene deficiency and after streptozotocin-induced diabetes in mouse pancreas. Am J Physiol Endocrinol Metab. 2006 Jan 31;291(1):E50-8.

85. De Leon DD, Farzad C, Crutchlow MF, Brestelli J, Tobias J, Kaestner $\mathrm{KH}$, et al. Identification of transcriptional targets during pancreatic growth after partial pancreatectomy and exendin-4 treatment. Physiol Genomics. 2006 Jan 12;24(2):133-43

86. Bockman DE, Merlino G. Cytological changes in the pancreas of transgenic mice overexpressing transforming growth factor alpha. Gastroenterology. 1992 Dec;103(6):1883-92.

87. Vinter-Jensen L, Juhl CO, Teglbjaerg PS, Poulsen SS, Dajani EZ, Nexo E. Systemic treatment with epidermal growth factor in pigs induces ductal proliferations in the pancreas. Gastroenterology. 1997 Oct;113(4):1367-74.

88. Rooman I, Lardon J, Flamez D, Schuit F, Bouwens L. Mitogenic effect of gastrin and expression of gastrin receptors in duct-like cells of rat pancreas. Gastroenterology. 2001 Oct;121(4):940-9.

89. Brand SJ, Tagerud S, Lambert P, Magil SG, Tatarkiewicz K, Doiron K, et al. Pharmacological treatment of chronic diabetes by stimulating pancreatic beta-cell regeneration with systemic co-administration of EGF and gastrin. Pharmacol Toxicol. 2002 Dec;91(6):414-20.

90. Suarez-Pinzon WL, Yan Y, Power R, Brand SJ, Rabinovitch A. Combination therapy with epidermal growth factor and gastrin increases beta-cell mass and reverses hyperglycemia in diabetic NOD mice. Diabetes. 2005 Sep;54(9):2596-601.

91. Wagner M, Luhrs H, Kloppel G, Adler G, Schmid RM. Malignant transformation of duct-like cells originating from acini in transforming growth factor transgenic mice. Gastroenterology. 1998 Nov;115(5):1254-62.

92. Means AL, Meszoely IM, Suzuki K, Miyamoto Y, Rustgi AK, Coffey RJ, Jr., et al. Pancreatic epithelial plasticity mediated by acinar cell transdifferentiation and generation of nestinpositive intermediates. Development. 2005 Aug;132(16):376776.

93. Rooman I, Lardon J, Bouwens L. Gastrin stimulates beta-cell neogenesis and increases islet mass from transdifferentiated but not from normal exocrine pancreas tissue. Diabetes. 2002 Mar;51(3):686-90.

94. Suarez-Pinzon WL, Lakey JR, Brand SJ, Rabinovitch A. Combination therapy with epidermal growth factor and gastrin induces neogenesis of human islet beta-cells from pancreatic duct cells and an increase in functional beta-cell mass. J Clin Endocrinol Metab. 2005 Jun;90(6):3401-9.

95. Lipsett MA, Castellarin ML, Rosenberg L. Acinar plasticity: Development of a novel in vitro model to study human acinarto-duct-to-islet differentiation. Pancreas. 2007 May 2007;34(4):452-7.

96. Lipsett M, Hanley S, Castellarin M, Austin E, Suarez-Pinzon WL, Rabinovitch A, et al. The role of islet neogenesis- associated protein (INGAP) in islet neogenesis. Cell Biochem Biophys. 2007;48(2-3):127-37.

97. Bani Sacchi T, Romagnoli P, Biliotti GC. The effects of chronic hypergastrinemia on human pancreas. J Submicrosc Cytol. 1983 Oct;15(4):1073-87.

98. Meier JJ, Butler AE, Galasso R, Rizza RA, Butler PC Increased islet beta cell replication adjacent to intrapancreatic gastrinomas in humans. Diabetologia. 2006 Nov;49(11):268996.

99. von Herrath M. E1-INT (Transition Therapeutics/Novo Nordisk). Curr Opin Investig Drugs. 2005 Oct;6(10):1037-42.

100. Suarez-Pinzon WL, Gotfredsen CF, Knudsen LB, Petersen JS, Rabinovitch A. Liraglutide, a long-acting GLP-1 analog, restores pancreatic beta-cell mass and corrects hyperglycemia after diabetes onset in NOD mice: Gastrin potentiates liraglutide's effects. Diabetes. 2005;54(Suppl 1):A57.

101. A 4-week therapy with Transition Therapeutics' E1-INT leads to sustained reductions in blood glucose levels for 6 months post-treatment in type 2 diabetes patients. (press release) Toronto, ON; June 28, 2007.

102. Habener JF, Drucker DJ, Mojsov S, Knepel W, Philippe J. Biosynthesis of glucagon. In: Samols E, editor. The Endocrine Pancreas. New York: Raven Press; 1991. p. 53-71.

103. Drucker DJ. Minireview: the glucagon-like peptides. Endocrinology. $2001 \mathrm{Feb}$;142(2):521-7.

104. Drucker DJ. Biological actions and therapeutic potential of the glucagon-like peptides. Gastroenterology. 2002 2/2002;122(2):531-44.

105. Goke R, Fehmann HC, Linn T, Schmidt H, Krause M, Eng J, et al. Exendin-4 is a high potency agonist and truncated exendin(9-39)-amide an antagonist at the glucagon-like peptide 1-(736)-amide receptor of insulin-secreting beta-cells. J Biol Chem. 1993 Sep 15;268(26):19650-5.

106. Kieffer TJ, McIntosh CH, Pederson RA. Degradation of glucose-dependent insulinotropic polypeptide and truncated glucagon-like peptide 1 in vitro and in vivo by dipeptidyl peptidase IV. Endocrinology. 1995 Aug;136(8):3585-96.

107. Stoffers DA, Kieffer TJ, Hussain MA, Drucker DJ, BonnerWeir S, Habener JF, et al. Insulinotropic glucagon-like peptide 1 agonists stimulate expression of homeodomain protein IDX1 and increase islet size in mouse pancreas. Diabetes. 2000 May;49(5):741-8.

108. Buteau J, Foisy S, Rhodes CJ, Carpenter L, Biden TJ, Prentki M. Protein kinase Czeta activation mediates glucagon-like peptide-1-induced pancreatic beta-cell proliferation. Diabetes. 2001 Oct;50(10):2237-43.

109. Tourrel C, Bailbe D, Meile MJ, Kergoat M, Portha B. Glucagon-like peptide-1 and exendin-4 stimulate beta-cell neogenesis in streptozotocin-treated newborn rats resulting in persistently improved glucose homeostasis at adult age. Diabetes. $2001 \mathrm{Jul} ; 50(7): 1562-70$.

110. Hui H, Wright C, Perfetti R. Glucagon-like peptide 1 induces differentiation of islet duodenal homeobox-1-positive pancreatic ductal cells into insulin-secreting cells. Diabetes. 2001 Apr;50(4):785-96.

111. Bulotta A, Hui H, Anastasi E, Bertolotto C, Boros LG, Di Mario U, et al. Cultured pancreatic ductal cells undergo cell cycle re-distribution and beta-cell-like differentiation in response to glucagon-like peptide-1. J Mol Endocrinol. 2002 Dec;29(3):347-60.

112. Abraham EJ, Leech CA, Lin JC, Zulewski H, Habener JF. Insulinotropic hormone glucagon-like peptide-1 differentiation of human pancreatic islet-derived progenitor cells into insulinproducing cells. Endocrinology. 2002 Aug;143(8):3152-61.

113. Xu G, Kaneto H, Lopez-Avalos MD, Weir GC, Bonner-Weir S. GLP-1/exendin-4 facilitates beta-cell neogenesis in rat and 
human pancreatic ducts. Diabetes Res Clin Pract. 2006 Jan 4;73(1):107-10.

114. Buteau J, Foisy S, Joly E, Prentki M. Glucagon-like peptide 1 induces pancreatic beta-cell proliferation via transactivation of the epidermal growth factor receptor. Diabetes. 2003 Jan;52(1):124-32.

115. Pospisilik JA, Martin J, Doty T, Ehses JA, Pamir N, Lynn FC, et al. Dipeptidyl peptidase IV inhibitor treatment stimulates beta-cell survival and islet neogenesis in streptozotocininduced diabetic rats. Diabetes. 2003 Mar;52(3):741-50.

116. Carpenter T, Trautmann ME, Baron AD. To the editor: Hyperinsulinemic hypoglycemia with nesidioblastosis after gastric-bypass surgery. N Engl J Med. 2005 Nov 17;353(20):2192.

117. Cummings DE. Gastric bypass and nesidioblastosis--too much of a good thing for islets? N Engl J Med. 2005 Jul 21;353(3):300-2.

118. Kaiser AM. To the editor: Hyperinsulinemic hypoglycemia with nesidioblastosis after gastric-bypass surgery. $\mathrm{N}$ Engl $\mathrm{J}$ Med. 2005 Nov 17;353(20):2192-3.

119. Scavini M, Pontiroli AE, Folli F. Asymptomatic hyperinsulinemic hypoglycemia after gastric banding. N Engl J Med. 2005 Dec 29;353(26):2822-3.

120. Service GJ, Thompson GB, Service FJ, Andrews JC, CollazoClavell ML, Lloyd RV. Hyperinsulinemic hypoglycemia with nesidioblastosis after gastric-bypass surgery. N Engl J Med. $2005 \mathrm{Jul}$ 21;353(3):249-54.

121. Yonemura Y, Takashima T, Miwa K, Miyazaki I, Yamamoto H, Okamoto H. Amelioration of diabetes mellitus in partially depancreatized rats by poly(ADP-ribose) synthetase inhibitors. Evidence of islet B-cell regeneration. Diabetes. 1984 Apr;33(4):401-4.

122. Terazono K, Yamamoto H, Takasawa S, Shiga K, Yonemura Y, Tochino Y, et al. A novel gene activated in regenerating islets. J Biol Chem. 1988 Feb 15;263(5):2111-4.

123. Terazono K, Uchiyama $\mathrm{Y}$, Ide $\mathrm{M}$, Watanabe $\mathrm{T}$, Yonekura $\mathrm{H}$, Yamamoto $\mathrm{H}$, et al. Expression of reg protein in rat regenerating islets and its co-localization with insulin in the beta cell secretory granules. Diabetologia. 1990 Apr;33(4):2502.

124. Rouquier S, Verdier JM, Iovanna J, Dagorn JC, Giorgi D. Rat pancreatic stone protein messenger RNA. Abundant expression in mature exocrine cells, regulation by food content, and sequence identity with the endocrine reg transcript. J Biol Chem. 1991 Jan 15;266(2):786-91.

125. Multigner L, De Caro A, Lombardo D, Campese D, Sarles H. Pancreatic stone protein, a phosphoprotein which inhibits calcium carbonate precipitation from human pancreatic juice. Biochem Biophys Res Commun. 1983 Jan 14;110(1):69-74.

126. Iovanna J, Orelle B, Keim V, Dagorn JC. Messenger RNA sequence and expression of rat pancreatitis-associated protein, a lectin-related protein overexpressed during acute experimental pancreatitis. J Biol Chem. 1991 Dec 25;266(36):24664-9.

127. Dieckgraefe BK, Crimmins DL, Landt V, Houchen C, Anant S, Porche-Sorbet R, et al. Expression of the regenerating gene family in inflammatory bowel disease mucosa: Reg Ialpha upregulation, processing, and antiapoptotic activity. J Investig Med. 2002 Nov;50(6):421-34.

128. Vasseur S, Folch-Puy E, Hlouschek V, Garcia S, Fiedler F, Lerch MM, et al. p8 improves pancreatic response to acute pancreatitis by enhancing the expression of the antiinflammatory protein pancreatitis-associated protein I. J Biol Chem. 2004 Feb 20;279(8):7199-207.

129. Christa L, Carnot F, Simon MT, Levavasseur F, Stinnakre MG, Lasserre C, et al. HIP/PAP is an adhesive protein expressed in hepatocarcinoma, normal Paneth, and pancreatic cells. Am J Physiol. 1996 Dec;271(6 Pt 1):G993-1002.

130. Gross DJ, Weiss L, Reibstein I, van den Brand J, Okamoto H, Clark A, et al. Amelioration of diabetes in nonobese diabetic mice with advanced disease by linomide-induced immunoregulation combined with Reg protein treatment. Endocrinology. 1998 May;139(5):2369-74.

131. Baeza NJ, Moriscot CI, Renaud WP, Okamoto H, Figarella CG, Vialettes BH. Pancreatic regenerating gene overexpression in the nonobese diabetic mouse during active diabetogenesis. Diabetes. 1996 Jan;45(1):67-70.

132. Baeza N, Sanchez D, Vialettes B, Figarella C. Specific reg II gene overexpression in the non-obese diabetic mouse pancreas during active diabetogenesis. FEBS Lett. 1997 Oct 27;416(3):364-8.

133. Sanchez D, Baeza N, Blouin R, Devaux C, Grondin G, Mabrouk K, et al. Overexpression of the reg gene in non-obese diabetic mouse pancreas during active diabetogenesis is restricted to exocrine tissue. J Histochem Cytochem. 2000 Oct;48(10):1401-10.

134. Unno M, Nata K, Noguchi N, Narushima Y, Akiyama T, Ikeda $\mathrm{T}$, et al. Production and characterization of Reg knockout mice: reduced proliferation of pancreatic beta-cells in Reg knockout mice. Diabetes. 2002 Dec;51(Suppl 3):S478-83.

135. Rafaeloff R, Pittenger GL, Barlow SW, Qin XF, Yan B, Rosenberg L, et al. Cloning and sequencing of the pancreatic islet neogenesis associated protein (INGAP) gene and its expression in islet neogenesis in hamsters. J Clin Invest. 1997 May 1;99(9):2100-9.

136. Zenilman ME, Magnuson TH, Swinson K, Egan J, Perfetti R, Shuldiner AR. Pancreatic thread protein is mitogenic to pancreatic-derived cells in culture. Gastroenterology. 1996 Apr;110(4):1208-14.

137. Levine JL, Patel KJ, Zheng Q, Shuldiner AR, Zenilman ME. A recombinant rat regenerating protein is mitogenic to pancreatic derived cells. J Surg Res. 2000 Mar;89(1):60-5.

138. Ortiz EM, Dusetti NJ, Vasseur S, Malka D, Bodeker H, Dagorn JC, et al. The pancreatitis-associated protein is induced by free radicals in AR4-2J cells and confers cell resistance to apoptosis. Gastroenterology. 1998 Apr;114(4):808-16.

139. Barbosa HC, Bordin S, Anhe G, Persaud SJ, Bowe J, Borelli $\mathrm{MI}$, et al. Islet neogenesis-associated protein signaling in neonatal pancreatic rat islets: involvement of the cholinergic pathway. J Endocrinol. 2008 Nov;199(2):299-306.

140. Fukui H, Kinoshita Y, Maekawa T, Okada A, Waki S, Hassan $\mathrm{S}$, et al. Regenerating gene protein may mediate gastric mucosal proliferation induced by hypergastrinemia in rats. Gastroenterology. 1998 Dec;115(6):1483-93.

141. Higham AD, Bishop LA, Dimaline R, Blackmore CG, Dobbins $\mathrm{AC}$, Varro A, et al. Mutations of RegIalpha are associated with enterochromaffin-like cell tumor development in patients with hypergastrinemia. Gastroenterology. 1999 Jun;116(6):1310-8.

142. Graf R, Schiesser M, Reding T, Appenzeller P, Sun LK, Fortunato F, et al. Exocrine Meets Endocrine: Pancreatic Stone Protein and Regenerating Protein-Two Sides of the Same Coin. J Surg Res. 2005 in press.

143. Laurine E, Manival X, Montgelard C, Bideau C, Berge-Lefranc JL, Erard M, et al. PAP IB, a new member of the Reg gene family: cloning, expression, structural properties, and evolution by gene duplication. Biochim Biophys Acta. 2005 Mar 10;1727(3):177-87.

144. Sasahara K, Yamaoka T, Moritani M, Yoshimoto K, Kuroda Y, Itakura M. Molecular cloning and tissue-specific expression of a new member of the regenerating protein family, islet neogenesis-associated protein-related protein. Biochim Biophys Acta. 2000 Jan 3;1500(1):142-6. 
145. Pittenger GL, Vinik AI, Rosenberg L. The partial isolation and characterization of ilotropin, a novel islet-specific growth factor. Adv Exp Med Biol. 1992;321:123-30; discussion 31-2.

146. Del Zotto H, Massa L, Rafaeloff R, Pittenger GL, Vinik A, Gold G, et al. Possible relationship between changes in islet neogenesis and islet neogenesis-associated protein-positive cell mass induced by sucrose administration to normal hamsters. J Endocrinol. 2000 Jun;165(3):725-33.

147. Gagliardino JJ, Del Zotto H, Massa L, Flores LE, Borelli MI. Pancreatic duodenal homeobox-1 and islet neogenesisassociated protein: a possible combined marker of activateable pancreatic cell precursors. J Endocrinol. 2003 May;177(2):249-59.

148. Rosenberg L, Lipsett M, Yoon JW, Prentki M, Wang R, Jun HS, et al. A pentadecapeptide fragment of islet neogenesisassociated protein increases beta-cell mass and reverses diabetes in C57BL/6J mice. Ann Surg. 2004 Nov;240(5):87584.
149. Borelli MI, Stoppiglia LF, Rezende LF, Flores LE, Del Zotto H, Boschero AC, et al. INGAP-related pentadecapeptide: its modulatory effect upon insulin secretion. Regul Pept. 2005 Nov;131(1-3):97-102.

150. Jamal AM, Lipsett M, Sladek R, Laganiere S, Hanley S, Rosenberg L. Morphogenetic plasticity of adult human pancreatic islets of Langerhans. Cell Death Differ. 2005 Jul;12(7):702-12.

151. Ratner RE, Feeley D, Buse JB, Schwartz SL, editors. Doubleblind, placebo-controlled trial of islet neogenesis gene associated protein (INGAP) in type 1 diabetes (T1DM) subjects. American Diabetes Association Annual Meeting; 2005; San Diego, CA.

152. Ratner RE, Feeley D, Buse JB, Fischer JS, editors. Doubleblind, placebo-controlled trial of islet neogenesis gene associated protein (INGAP) therapy in type 2 diabetes (T2DM) subjects. American Diabetes Association Annual Meeting; 2005; San Diego, CA.

Stephen Hanley (M.D., C.M. 2011) completed a BSc in Biochemistry and Pharmacology \& Therapeutics (2002) and a PhD in Experimental Surgery (2009), both from McGill University. He is currently a medical student at McGill University, with active research interests in gastrointestinal endocrinology and pancreatic regeneration. 